\title{
GAMBARAN PENGETAHUAN PERAWAT TENTANG INTERVENSI MANDIRI VENTILATOR ASSOCIATED PNEUMONIA BUNDLE CARE PADA PASIEN DENGAN VENTILASI MEKANIK DI UNIT PERAWATAN INTENSIF
}

\author{
Ariza Widya Rahma ${ }^{1}$, Suhartini Ismail ${ }^{2}$ \\ ${ }^{1}$ Jurusan Keperawatan, Fakultas Kedokteran, Universitas Diponegoro \\ ${ }^{2}$ Departeman Keperawatan Medikal Bedah, Jurusan Keperawatan, Fakultas Kedokteran, \\ Universitas Diponegoro \\ Suhartini.ismail@ @ fk.undip.ac.id
}

\begin{abstract}
Abstrak
Risiko VAP pada pasien terintubasi ventilasi mekanik disebabkan oleh tabung endotrakeal yang terpasang invasive memungkinkan masuknya bakteri secara langsung ke saluran pernapasan bagian bawah. VAP Bundle Care terbukti dapat mengurangi VAP dan meningkatkan hasil positif bagi pasien. Pengetahuan perawat menjadi salah satu indikator keberhasilan VAP Bundle Care karena pengetahuan berpengaruh terhadap terbentuknya perilaku perawat. Penelitian ini bertujuan untuk mengidentifikasi tingkat pengetahuan perawat ICU tentang intervensi mandiri VAP Bundle Care. Desain penelitian ini adalah kuantitatif deskriptif dengan metode survey. Teknik sampling yang digunakan yaitu total sampling. Sebanyak 100 perawat ICU berpartisipasi. Pengambilan data menggunakan critical care nurses' knowledge of evidence based guidelines for preventing ventilator associated pneumonia: an evaluation questionnaire. Face validity dan item validity telah dilakukan. Hasil reliabilitas kuesioner memiliki koefisien alpha 0,529. Analisis data yang digunakan yaitu analisis univariate dengan bentuk distribusi frekuensi. Hasil penelitian menunjukkan bahwa $65 \%$ perawat ICU memiliki pengetahuan sedang tentang intervensi mandiri VAP Bundle Care. Kesimpulan dari penelitian ini adalah lebih banyak perawat ICU yang memiliki pengetahuan sedang daripada perawat dengan pengetahuan kurang. Penelitian ini diharapkan dapat menjadi saran baik perawat, instansi rumah sakit, institusi pendidikan, peneliti selanjutnya untuk memaksimalkan pengetahuan tentang VAP Bundle Care.
\end{abstract}

Kata kunci: Pengetahuan perawat, unit perawatan intensif, vap bundle care, ventilasi mekanik

\begin{abstract}
Analysis of nurse knowledge about mandiri intervention of associated pneumonia bundle care in patients with mechanical ventilation in intensive care units. Risks of ventilator-associated pneumonia $(V A P)$ in intubated patients receiving mechanical ventilation is due to an invasive endotracheal tube that may enable bacteria to enter directly into the lower respiratory tract. VAP bundle care has been proven to reduce VAP and improve positive outcomes for patients. Nurses' knowledge is one of the indicators of the success of VAP bundle care since it influences the formation of nurses' behaviors. This study aimed to identify the knowledge level of ICU nurses about VAP bundle care independent intervention. This study employed a quantitative descriptive design with survey methods. A total of 100 ICU nurses recruited using total sampling participated in this study. The data were collected using the critical care nurses and ventilator-associated pneumonia: an evaluation questionnaire. The face validity and item validity tests were performed. The result of the reliability test obtained an alpha coefficient of 0.529. The collected data were analyzed using a univariate analysis in the form of frequency distribution. The results showed that $65 \%$ of the ICU nurses had a moderate level of knowledge about VAP bundle care independent intervention. This study concluded that more ICU nurses had a moderate level of knowledge than those who had an inadequate level of knowledge. This study is expected to be a suggestion for nurses, hospital agencies, educational institutions, and further researchers to optimize the knowledge of VAP bundle care
\end{abstract}

Keywords: Intensive Care Unit, Nurses' Knowledge, Mechanical Ventilation, VAP Bundle Care

\section{Pendahuluan}

VAP (Ventilator Associated

Pneumonia) merupakan penyakit infeksi pneumonia terkait pelayanan kesehatan atau Healthcare Associated Infection (HAIs) yang paling umum ditemukan di
Intensive Care Unit (ICU) (Kemenkes RI, 2017). Risiko VAP pada pasien terintubasi ventilasi mekanik meningkat disebabkan oleh tabung endotrakeal yang terpasang invasif memungkinkan masuknya bakteri secara langsung ke saluran pernapasan 
bagian bawah karena tabung berada di trakea. Kolonisasi bakteri pada saluran pernapasan lebih lanjut difasilitasi oleh tidak adanya refleks batuk dan sekresi lendir yang berlebihan pada pasien dengan ventilasi mekanik (Yunita \& Rondhianto, 2015).

VAP Bundle Care terbukti dapat mengurangi VAP dan meningkatan hasil positif bagi pasien. Strategi VAP Bundle Care bertujuan untuk mencegah terjadinya VAP yang difokuskan pada usaha menurunkan kolonisasi bakteri di orofaring dan saluran trakeobronkial, serta menurunkan hal-hal yang menyebabkan terjadinya aspirasi, atau keduanya (Afif \& Fuadi dkk., 2014). VAP Bundle Care terdiri dari tindakan kolaborasi dan tindakan mandiri, sehingga perawat sebagai tenaga kesehatan professional harus mampu melakukan Independent implementations sesuai evidence based VAP Bundle Care. Keberhasilan VAP bundle care di ruang rawat intensif oleh perawat bergantung pada standar prosedur operasional, tingkat pengetahuan perawat terhadap VAP bundle care, serta kepatuhan tindakan keperawatan (Sadli \& Tavianto dkk., 2017).

Pengetahuan menjadi salah satu indikator keberhasilan VAP bundle care, karena pengetahuan berpengaruh terhadap terbentuknya perilaku perawat dalam melakukan penerapan VAP bundle care. Pengetahuan perlu dimiliki perawat agar apa yang dilakukan, memiliki dasar dan dapat dipertanggungjawabkan. Pengetahuan yang baik akan mendasari skill yang baik, namun skill tanpa pengatahuan atau dengan pengetahuan yang rendah akan menghasilkan kualitas pelayanan keperawatan yang kurang maksimal.

\section{Metode}

Penelitian ini menggunakan jenis penelitian kuantitatif. Rancangan penelitian ini menggunakan desain penelitian deskriptif dengan metode survey. Teknik pengambilan sampel yang digunakan adalah total sampling, dengan jumlah sampel sebesar 100 perawat ICU di Semarang yang menjadi anggota HIPERCCI Jawa Tengah. Penelitian ini menggunakan critical care nurses' knowledge of evidence based guidelines for preventing ventilator associated pneumonia: an evaluation questionnaire yang dikembangkan oleh S. Labeu \& Vandijck et al. Kuesioner tersebut terdiri dari 9 pertanyaan pilihan ganda tentang VAP Bundle Care, dengan ketentukan skor 1 untuk setiap jawaban benar dan skor 0 untuk setiap jawaban salah. Hasil pengukuran menggunakan cut of point dari nilai skor yang telah dicapai oleh responden dalam hasil penelitian mean \pm st.deviasi $(4,66 \pm 1,603)$ dengan kategori pengetahuan tinggi (skor 7,8,9), sedang $(4,5,6)$, rendah $(1,2,3)$.

Uji validitas kuesioner dinyatakan valid dengan face validity dan item validity. Terdapat 2 item pertayaan yang memiliki nilai validity 0,254 dan 0,373 , namun tetap dicantumkan dalam kuesioner karena kedua pertanyaan tersebut penting untuk mengukur tingkat pengetahuan perawat tentang VAP Bundle Care. Kuesioner dinyatakan cukup reliabel dengan nilai koefisien Alpha Cronbach 0,529 . Analisis data menggunakan analisis univariate dengan bentuk distribusi frekuensi. Penelitian ini telah disetujui oleh Komisi Etik Penelitian Kesehatan Fakultas Kedokteran Universitas Diponegoro dan RSUP Dr. Kariadi Semarang dengan No.366/EC/FK-RSDK/V/2018.

\section{Hasil \\ Karakteristik Responden}

Karakteristik responden meliputi usia, pendidikan, jenis kelamin, lama kerja. Usia mayoritas responden pada penelitian ini adalah 31-40 tahun (48\%). Mayoritas responden pada penelitian ini berpendidikan D3 (56\%), kemudian sebanyak (30\%) memiliki kualifikasi pendidikan Ners. Sebesar 67\% dalam penelitian ini adalah perawat ICU perempuan. Sebagian besar responden dalam penelitian ini memiliki masa kerja lebih dari lima tahun, yaitu sebanyak 51\% (Tabel 1). 
Tabel 1

Karakteristik Responden $(n=100)$

\begin{tabular}{lcc}
\hline Karakteristik Demografi & $\mathrm{f}$ & $\%$ \\
\hline Umur & 41 & 41 \\
20-30 tahun & 48 & 48 \\
$31-40$ tahun & 11 & 11 \\
$41-50$ tahun & & \\
Pendidikan & 56 & 56 \\
D3 Keperawatan & 1 & 1 \\
D4 Keperawatan & 7 & 7 \\
S1 Keperawatan & 30 & 30 \\
Ners & 6 & 6 \\
S2 Keperawatan & 0 & 0 \\
S3 Keperawatan & & \\
Jenis Kelamin & 33 & 33 \\
Laki-laki & 67 & 67 \\
Perempuan & & \\
Lama Kerja di ICU & 15 & 15 \\
< tahun & 24 & 24 \\
2-3 tahun & 10 & 10 \\
4-5 tahun & 51 & 51 \\
$>5$ tahun & &
\end{tabular}

Pengetahuan Perawat Tentang Intervensi Mandiri VAP Bundle Care

Berdasarkan hasil penelitian, $65 \%$ perawat ICU memiliki pengetahuan sedang, dan hanya $12 \%$ memiliki pengetahuan tinggi tentang intervensi mandiri VAP Bundle Care pada Pasien dengan Ventilasi Mekanik di ICU.
Tendensi sentral tingkat pengetahuan perawat juga menunjukkan bahwa perawat memiliki tingkat pengetahuan sedang tentang intervensi mandiri VAP Bundle Care pada pasien dengan ventilasi mekanik di ICU (mean=4,66, median $=5,00$, modus $=5)($ Tabel 2$)$.

Tabel 2

Pengetahuan Berdasarkan Kategori Pengetahuan Perawat Tentang Intervensi Mandiri VAP Bundle Care Pada Pasien dengan Ventilasi Mekanik $(\mathrm{n}=100)$

\begin{tabular}{lcc}
\hline \multicolumn{1}{c}{ Kategori Pengetahuan } & $\mathrm{f}$ & $\%$ \\
\hline Tinggi & 12 & 12 \\
Sedang & 65 & 65 \\
Rendah & 23 & 23 \\
\hline
\end{tabular}

*Mean $=4,66 \quad ;$ Median $=5,00 \quad ;$ Mode $=5$

\section{Pembahasan}

Hasil penelitian ini menunjukkan bahwa mayoritas responden memiliki pengetahuan sedang sebesar $65 \%$ tentang intervensi mandiri VAP Bundle Care. Sesuai dengan hasil penelitian tahun 2014, yang menghasilkan bahwa pengetahuan dari critical care provider di ICU yang terdiri dari perawat, fisioterapis, dan respiratory therapist memiliki pengetahuan yang adekuat sebesar 55,80\% tentang pencegahan VAP yang dikaji dengan menggunakan kuesioner terstruktur tentang pencegahan VAP yang dikelola sendiri oleh peneliti (Sherpa \& Chakrabarty et al., 2014).

Perbedaan skor hasil penelitian dengan hasil penelitian tahun 2014 tersebut dapat disebabkan karena perawat ICU yang menjadi fokus penelitian ini merupakan bagian integral dari pelayanan kesehatan pasien dengan ventilasi mekanik di Rumah Sakit. Perawat ICU merupakan tenaga kesehatan yang bertugas selama 24 jam bergantian secara shift memberikan perawatan pasien dengan ventilasi mekanik, sehingga perawat sering menjadi orang pertama yang mengetahui perubahan 
pada pasien dengan ventilasi mekanik berdasarkan kajian fisik. Kondisi tersebut dapat menyebabkan perawat ICU memiliki pengetahuan yang lebih baik tentang VAP dan pencegahannya. Hal in sesuai dengan teori bahwa perawat ICU memiliki tanggung jawab penting dalam menerapkan dan mengawasi keberjalanan bundle perawatan. berdasarkan tanggung jawab tersebut, perawat menyadari bahwa VAP sebagai salah satu HAIs dapat dicegah dengan perawat tetap mengikuti langkah-langkah sesuai evidence untuk mencegah dan mengendalikan infeksi dan memberikan perawatan yang paling efektif untuk pasien dengan memperkuat pengetahuan mereka (Yazici \& Bulut, 2018).

Perawat dalam memperkuat pengetahuannya tentang intervensi mandiri VAP Bundle Care dapat melalui akses informasi dari kolaborasi multidisiplin. Kolaborasi multidisiplin dibutuhkan dalam perawatan pasien dengan ventilasi mekanik di ICU. Kolaborasi dengan keperawatan, tim multidisiplin serta pengarahan dari tim PPI di Rumah Sakit pada lingkungan kerja ini memungkinkan anggota tim untuk bertukar pengetahuan, sehingga perawat mendapat akses informasi tentang VAP Bundle Care. Pada penelitian ini, tingkat pengetahuan yang berkaitan dengan tiga komponen yaitu intubasi oral, suction dan head of bed $30-45^{0}$ juga berada dalam kategori sedang. Pengetahuan sedang perawat ICU disebabkan karena sampel penelitian adalah perawat HIPERCCI yang selalu mengupgrade pengetahuan melalui pelatihan atau diskusi anggota pada pertemuan yang diselenggarakan rutin. Hal ini sesuai dengan teori bahwa, lingkungan berpengaruh terhadap proses masuknya pengetahuan (Budiman \& Riyanto, 2013).

Lingkungan yang baik akan mempengaruhi pengetahuan yang baik, karena lingkungan yang baik menyediakan sumber informasi yang lebih banyak sehingga perawat akan mendapat pengetahuan yang jelas (Rifai, 2016).
Pengetahuan sedang yang dimiliki perawat ICU tentang VAP Bundle Care juga disebabkan karena perawatan pasien dengan ventilasi mekanik merupakan salah satu standar kompetensi yang harus perawat ICU miliki. Perawat ICU akan berusaha memenuhi standar kompetensi tersebut untuk memenuhi kualifikasi sebagai perawat ICU, sehingga perawat akan terdorong untuk berusaha mempelajari VAP Bundle care, agar dapat mencegah infeksi pada pasien dengan ventilasi mekanik secara maksimal sesuai dengan standar perawatan pasien dengan ventilasi mekanik.

Salah satu usaha untuk meningkatkan pengetahuan perawat tentang VAP Bundle Care adalah dengan perawat mengikuti pelatihan atau seminar yang diselenggarakan oleh Rumah Sakit atau institusi lain. Hal ini sesuai dengan penelitian Badawy (2014) yang menyebutkan bahwa program pendidikan terstruktur terkait VAP dan pencegahannya selama dua minggu dengan 3 sesi setiap minggu selama 20 menit terbukti efektif meningkatkan skor pengetahuan perawat.

Hasil penelitian ini juga menunjukkan bahwa terdapat $23 \%$ perawat yang memiliki pengetahuan kurang tentang intervensi mandiri VAP Bundle Care. Hal ini berbeda dengan hasil penelitian AlSayaghi (2014), yang menyebutkan bahwa mayoritas perawat yang bekerja di ICU, $73,4 \%$ dari 513 perawat memiliki pengetahuan rendah tentang evidence based strategies untuk mencegah VAP. Pengetahuan kurang perawat ICU disebabkan karena $>75 \%$ perawat dalam penelitian adalah perawat D3. Perawat D3 dianggap belum memiliki cukup pengetahuan untuk memberikan perawatan berdasarkan bukti atau perawatan khusus. Tingkat pendidikan keperawatan memiliki pengaruh kuat pada tingkat pengetahuan. Ketika tingkat pendidikan perawat meningkat, tingkat pengetahuan mereka juga meningkat (Al-Sayaghi, 2014).

Hasil penelitian Al-Sayaghi pada tahun 2014 berbeda dengan penelitian ini, 
dimana meskipun mayoritas responden dalam penelitian ini memiliki kualifikasi pendidikan D3, namun tingkat pengetahuan perawat tentang intervensi mandiri VAP Bundle Care memiliki tingkat sedang. Banyaknya perawat dengan kualifikasi D3 di Rumah sakit dapat disebabkan karena proses rekruitmen Rumah Sakit yang mayoritas membutuhkan perawat D3, adanya suatu prosedural dari $\mathrm{RS}$ mengenai tugas dan izin belajar atau masih rendahnya kemauan perawat untuk meneruskan pendidikan ke jenjang yang lebih tinggi (Nurmiati \& Karim dkk., 2010).

Semakin tingginya tingkat pendidikan maka perawat akan mudah dalam menyerap informasi dan cepat pula dalam mengimplementasikan pengetahuan yang dimiliki oleh perawat khususnya untuk mencegah pneumonia dengan VAP Bundle Care (Marlina, 2013). Hal ini berbeda dengan penelitian Rifai (2016), yang menyebutkan bahwa tidak terdapat hubungan antara pendidikan dengan pengetahuan perawat tentang pencegahan VAP, sehingga hasil penelitian yang menjelaskan bahwa pengetahuan perawat sedang tentang intervensi mandiri VAP Bundle Care meskipun mayoritas perawat memiliki kualifikasi D3 dapat dipengaruhi faktor lain, seperti lamanya masa kerja perawat.

Masa kerja merupakan salah satu faktor yang berhubungan dengan pengetahuan. Perawat yang mempunyai banyak pengalaman lapangan baik pengalaman yang positif maupun negatif, akan menambah kepekaannya terhadap masalah di bidangnya, sehingga semakin lama masa kerja, semakin banyak pengalaman yang didapat, maka semakin baik pula pengetahuan yang diperoleh (Rifai, 2016). Pengalaman profesional dalam perawatan intensif dapat menjadi faktor penting dalam memperoleh pengetahuan tentang pencegahan VAP (Llaurado \& Lebau et al., 2011).

Pengetahuan sedang perawat tentang intervensi mandiri VAP Bundle
Care yang menjadi hasil dalam penelitian ini sejalan dengan karakteristik responden, dimana mayoritas responden adalah perawat ICU dengan lama kerja mayoritas sudah lebih dari lima tahun. Berdasarkan penelitian Labeau \& Vandijck et al (2008), menyebutkan bahwa perawat yang memiliki pengalaman kerja lebih dari 5 tahun memiliki pengetahuan terkait pencegahan VAP yang lebih baik dibanding dengan perawat yang memiliki pengalaman kerja kurang dari 5 tahun.

Perawat yang memiliki pengetahuan kurang sebesar $23 \%$ dalam hasil penelitian ini dapat disebabkan karena perawat belum melakukan update ilmu pengetahuan tentang VAP Bundle Care. Salah satu cara untuk melakukan update ilmu pengetahuan adalah dengan membaca literature. Di Indonesia, sumber bacaan terkait evidence based tentang VAP Bundle Care perlu ditingkatkan, karena mayoritas sumber bacaan VAP Bundle Care dapat diasumsikan berkapasitas Bahasa Inggris, sehingga perlu ditingkatkan keinginan perawat untuk membaca tentang isi dari sebuah artikel tersebut dengan upaya yang maksimal.

Upaya dalam meningkatkan minat baca dipengaruhi oleh beberapa faktor, yaitu faktor dorongan langsung maupun tidak langsung. Faktor dorongan langsung dapat berupa dukungan dari teman sejawat, atau dorongan dari kepala ruang, sedangkan faktor tidak langsung dapat berasal dari sumber bacaan (penyedia), misalnya langganan jurnal yang ada di rumah sakit sebagai fasilitas baca perawat. Menurunnya minat baca dapat disebabkan kurang paripurnanya dorongan yang didapat, bisa berasal dari dorongan langsung maupun tidak langsung (Sutarno, 2006).

Intervensi mandiri terkait VAP Bundle Care penting untuk diketahui perawat karena pengetahuan merupakan hal vital yang mempengaruhi perilaku. Pengetahuan baik akan mendorong perawat untuk memberikan asuhan keperawatan dan tindakan pencegahan 
terkait VAP (Marlina, 2013). Hal ini sesuai dengan penelitian Idawaty (2016) yang menyebutkan bahwa terdapat hubungan yang bermakna antara tingkat pengetahuan perawat tentang perawatan ventilasi mekanik dengan penerapan VAP Bundle pada tahun 2016.

Pengetahuan baik tentang VAP Bundle Care yang dimiliki perawat akan berdampak pada perilaku positif terhadap perawatan pasien dengan ventilasi mekanik di ICU, sehingga perawat sebagai tumpuan dalam hal mencegah VAP, harus mengusai VAP Bundle Care. VAP Bundle Care terdiri dari berbagai komponen seperti intubasi oral, suction, dan head of bed 30$45^{\circ}$ yang berdasarkan evidence based, efektif mencegahan VAP apabila dilakukan secara bersamaan.

Program tersebut tidak lagi menjadi program yang hanya satu persatu dikerjakan oleh perawat tetapi menjadi satu program secara keseluruhan yang dihasilkan dari sebuah evidence based untuk diterapkan langsung kepada pasien untuk mencegah terjadinya VAP. Penerapan VAP Bundle Care oleh perawat terbukti dapat menurunkan kejadian VAP, sesuai dengan penelitian Alcan \& Uyar et al (2016) yang menyebutkan bahwa terjadi penurunan secara signifikan terkait kejadian VAP setelah penerapan VAP Bundle oleh perawat, dari 23 kejadian VAP dengan laju 15,91/1000 hari ventilator pada fase pre-implementasi menjadi 10 kejadian VAP dengan laju $8,50 / 1000$ hari ventilator pada fase postimplementasi.

\section{Simpulan dan Saran}

Hasil penelitian menunjukkan bahwa tingkat pengetahuan perawat tentang intervensi mandiri VAP Bundle Care pada pasien dengan ventilasi mekanik, $65 \%$ memiliki pengetahuan sedang, sehingga dapat disimpulkan bahwa lebih banyak perawat ICU yang memiliki pengetahuan sedang daripada perawat yang memiliki pengetahuan kurang tentang intervensi mandiri VAP Bundle Care. Pengetahuan tidak selalu menjamin implementasi dan kepatuhan, namun kurangnya pengetahuan dapat menjadi penghalang terhadap implementasi dan kepatuhan perawat.

\section{Daftar Pustaka}

Alcan, A.O., Korkmaz, D.F., Uyar,M. (2016). Prevention of ventilatorassociated pneumonia: Use of the care bundle approach. American Journal of Infection Control, 44 (10):173-6.

Al-sayaghi, K. M. (2014). Prevention of ventilator-associated pneumonia. Saudi Med Journal, 35(3), 269-76.

Badawy, A.I. (2014). Impact of a structured teaching program for prevention of ventilator associated pneumonia on knowledge and practices of intensive care nurses at Central Quwesna hospital, Egypt. Medical Journal Cairo University, 82(1), 803-13.

Budiman, \& Riyanto, A.(2013). Kapita Selekta Kuisioner Pengetahuan Dan Sikap Dalam Penelitian Kesehatan. Jakarta: Salemba Medika

Idawaty, S. (2016). Hubungan tingkat pengetahuan tenaga kesehatan dengan penerapan VAP Bundle di ICU RSUP Dr. Djamil Padang (Thesis). Univ Andalas.

Labeau, S., Vandijck, D., Rello, J., Adam, S., et al. (2008). Evidence-based guidelines for the prevention of ventilator-associated pneumonia: results of a knowledge test among European intensive care nurses. Hospital Infection Journal, 70(2), 180-5.

Labeau, S., Vandijck, D., Claes, B., Van Aken, P., \& Blot, S. (2007). Critical care nurses' knowledge of evidence-bases guidelines for 
preventing ventilator-associated pneumonia: An evaluation questionnaire. American Journal of Critical Care, 16(4), 371-7.

Llaurado, M., Labeau, S., Vandijck, D., Rello, J., et al. (2011). Southern European Intensive Care Nurses' Knowledge of Evidence-Based Guidelines for Preventing Ventilator-Associated Pneumonia. Medicina Intensiva, 35 (1), 6-12.

Marlina, Hairanisa. (2013). Pengetahuan perawat pelaksanan dan pencegahan pneumonia pada pasien tirah baring di RSUD ZA Banda Aceh. Idea Nursing Journal, 4(1), $51-61$.

Menteri Kesehatan RI. (2017). Peraturan Menteri Kesehatan Nomor 27 Tahun 2017 tentang Pedoman Pencegahan Dan Pengendalian Infeksi Di Fasilitas Pelayanan Kesehatan. 1-172.

Nurmiati., Karim, D., \& Jumaini. (2010). Hubungan antara pengetahuan perawat tentang perawatan pasien dengan ventilator dan sikap perawat terhadap tindakan suction. $1-9$.

Rifai, A. (2016). Analisis faktor-faktor yang berhubungan dengan pengetahuan perawat tentang pencegahan ventilator associated pneumonia (VAP) di Ruang ICU RSUD Dr. Moewardi. Jurnal keperawatan Global, 1(2), 64-72.

S. Afif, A., Fuadi, I,. \& Maskoen, T.T. (2014). Pengaruh penggunaan pipa endotrakea dengan drainase sekret subglotis terhadap kejadian ventilator associated pneumonia (VAP) di Intensive Care Unit (ICU) Rumah Sakit Dr . Hasan Sadikin Bandung. Anesthesia \& Critical Care Journal, 32(1),18-25.
Sadli, M.F., Tavianto, D., \& Redjek, I. (2017). Gambaran Pengetahuan Klinisi Ruang Rawat Intensif mengenai Ventilator Associated Pneumonia (VAP) Bundle di Ruang Rawat Intensif RSUP Dr. Hasan Sadikin Bandung. Jurnal Anastesi Perioperatif, 5(2), 85-93.

Sherpa, P.C., Chakrabarty, J., D'Souza, P.J.J., \& Varma, M. (2014). Knowledge of critical care provider on prevention of ventilator associated pneumonia. Journal of Krishna Institute Medical Sciences (JKIMSU), 3(1), 80-4.

Sutarno, N. (2006). Perpustakaan dan Masyarakat: Edisi revisi. Jakarta: Sagung Seto.

Yazici, G., Bulut, H. (2018). Efficacy of a care bundle to prevent multiple infections in the intensive care unit: A quasi-experimental pretestposttest design study. Applied Nursing Research, 39,4-10.

Yunita, R., \& Rondhianto, W. (2015). Pengaruh open suction system terhadap kolonisasi staphylococcus aureus pada pasien dengan ventilator mekanik di Ruang Intensive Care Unit (ICU) RSD dr. Soebandi Jember. E-Jurnal Pustaka Kesehatan, 3(1),103-10. 